has provoked most interest among patients, giving rise to new optimism. It does, however, present more challenges to the clinician, who now has to decide which patients are medically and psychologically suitable for transplantation. Donor organs are limited and selection is therefore essential; like all the changes that have led to increased survival of these patients transplantation has appreciable financial implications. ${ }^{36}$

MARGARET E HODSON

Reader in Respiratory Medicine

and Honorary Consultant Physician,

National Heart and Lung Institute

and Brompton Hospital,

London SW3 6HP

1 Andersen DH. Cystic fibrosis of the pancreas and its relation to celiac disease. A clinical and pathological study. Am $\mathcal{F}$ Dis Child 1938;56:344-99.

2 British Paediatric Association Working Party on Cystic Fibrosis. Cystic fibrosis in the United Kingdom 1977-85: an improving picture. Br Med f 1988;297:1599-602.

Hodson ME, Beldon I, Power R, Duncan FR, Bamber M, Batten JC. Sweat tests to diagnose cystic
Hom fibrosis in adults. Br Med $\mathcal{F}$ 1983;286:1381-3.

4 Penketh ARL, Wise A, Mearns MB, Hodson ME, Batten JC. Cystic fibrosis in adolescents and adults. Thorax 1987;42:526-32.

5 Hodson ME, Gaskell DV. Physiotherapy. In: Hodson ME, Norman A, Batten JC, eds. Cystic fibrosis. London: Baillière Tindall, 1983:219-41.

6 Batten JC. In: Advanced medicine. London: Pitman, 1983

7 Hodson ME, Roberts CM, Butland RJA, Smith MJ, Batten JC. Oral ciprofloxacin compared with conventional intravenous treatment for Pseudomonas aeruginosa infection in adults with cystic fibrosis. Lancet 1987; ; $235-7$.

8 Michel BC. Antibacterial therapy in cystic fibrosis. Chest 1988;84:129-40S

9 Hodson ME, Penketh A, Batten JC. Aerosol carbenicillin and gentamicin in the treatment of Pseudomonas aeruginosa infection in patients with cystic fibrosis. Lancet 1981;ii:1137-9.

10 Kuzemko JA. Home treatment of pulmonary infections in cystic fibrosis. Chest 1988;94:162-6S.

11 Stead RJ, Davidson TI, Duncan FR, Hodson ME, Batten JC. Use of a totally implantable system for venous access in cystic fibrosis. Thorax 1987;42:149-50.

2 Efthimiou J, Taylor $P$, Hodson ME, Batten JC. Importance of viruses and Legionella pneumophila in respiratory exacerbations of patients with cystic fibrosis. Thorax 1984;39:150-4.
13 Smith MJ, Efthimiou J, Hodson ME, Batten JC. Mycobacterial isolations in young adults with cystic fibrosis. Thorax 1984;39:369-75.

4 Penketh ARL, Knight R, Hodson ME, Batten JC. The management of pneumothorax in adults. Thorax 1982;37:850-3.

5 Stern RC, Boat RF, Orenstein DM, Wood RE, Matthews LW, Doershuk CF. Treatment and prognosis of lobar and segmental atelectasis in cystic fibrosis. Am Rev Respir Dis 1978;118:821-6.

6 Brueton MJ, Ormerod LP, Shah KJ, Anderson CM. Allergic bronchopulmonary aspergillosis complicating cystic fibrosis in childhood. Arch Dis Child 1980;55:348-53.

17 Fairfax AJ, Ball J, Batten JC, Heard BE. A pathological study following bronchial artery embolisation for haemoptysis in cystic fibrosis. Brf Dis Chest 1980;74:345-52.

18 Shwachman H. Gastrointestinal manifestations of cystic fibrosis. Pediatr Clin North Am 1975;22 787-805.

19 Beverlev DW, Kelleher J, Macdonald A, Littlewood JM, Robinson T, Walters MP. Comparison of four pancreatic extracts in cystic fibrosis. Arch Dis Child 1987;62:564-8.

20 Congden PJ, Bruce G, Rothburn MM, et al. Vitamin status in treated patients with cystic fibrosis. Arch Dis Child 1981;56:708-14.

21 Hodson ME, Mearns MB, Batten JC. Meconium ileus equivalent in adults with cystic fibrosis. BrMed F 1976;ii:790-1.

22 Cleghorn GJ, Fortstner GG, Stringer DA, et al. Treatment of distal intestinal obstruction syndrome in cystic fibrosis with a balanced intestinal lavage solution. Lancet 1986;i:8-11.

23 Psacharopollos HT, Mowat AP. The liver and biliary system. In: Hodson ME, Batten JC, Norman AP, eds. Cystic fibrosis. London: Baillière Tindall, 1983:164-82.

24 Penketh ARL, Wise A, Mearns MB, Hodson ME, Batten JC. Cystic fibrosis in adolescents and adults. Thorax 1987:42:526-32.

25 Chalton R, Mackay I, Wilson R, et al. Double-blind, placebo controlled trial of betamethasone nasal drops for nasal polyposis. Br.Med $\mathcal{F}$ 1985;291:788.

26 Pryor J, Crawford AD. Systemic amyloidosis complicating cystic fibrosis. Br $\mathcal{J}$ Dis Chest $1980 ; 74: 84-6$

27 Agnese PAD-S, Davis PB. Cystic fibrosis in adults, 75 cases and a review of 232 cases in the literature. Am J Med 1979;66:121-32.

28 Dixey JJ, Redington AN, Butler RC, et al. The arthropathy of cystic fibrosis. Ann Rheum Dis 1988;47:218-23.

29 Finnegan MJ, Jayne D, Neill S, Hodson ME. Vasculitis complicating cystic fibrosis. Thorax (in

press).
30 Pinkerton $P$, Trauer R, Duncan F, Hodson ME, Batten JC. Cystic fibrosis in adult life: a study of coping patterns. Lancet 1985;ii:761-3.

31 Norman AP, Hodson ME. Psychological and social aspects. In: Hodson ME, Batten JC, Norman AP, eds. Cystic fibrosis. London: Baillière Tindall, 1983:242-59.

32 Phelan P, Hey E. Cystic fibrosis mortality in England and Wales and in Victoria, Australia. Arch Dis Child 1984;59:71-3.

33 Hoiby N. Microbiology of lung infections in cystic fibrosis patients. Acta Paediatr Scand [Suppl] 1982:301:33-54

34 Scott J, Hutter J, Stewart S, et al. Heart-lung transplantation for cystic fibrosis. Lancet 1988;ii: $192-4$

35 Geddes DM, Hodson ME. Heart lung transplantation in cystic fibrosis. $\mathcal{Y} R$ Soc Med (in press)

36 Capewell G. Cystic fibrosis. London: Office of Health Economics, 1986:1-41.

\title{
Conflict over drug policy in Australia
}

\section{The need for change}

In Australia the government, the doctors, and the pharmaceutical companies are at loggerheads over a plan to reduce the rapidly rising cost of drugs to the health service. The argument threatens the future of the pharmaceutical benefits scheme in its present form.

The Pharmaceutical Benefits Act was introduced in Australia in 1950 to provide a range of drugs without cost to patients. In 1951 a wider range of drugs was made available free of charge to pensioners. In 1960 the scheme was expanded: the general and pensioner schemes were amalgamated, and almost the entire range of drugs in both schemes were made available to the general public. People other than pensioners were required to pay 50 cents for each prescription, and since then there have been regular adjustments: the cost now is $\$ A 11$ to a general patient and $\$ A 2.50$ for disadvantaged patients. There is no charge to pensioners.

The scheme has served Australia well. Drugs are cheap by standards in the developed world: the manufacturer's yearly revenue for each inhabitant was \$47 in Australia in 1987 compared with $\$ 73$ in New Zealand, $\$ 68$ in Britain, $\$ 105$ in Canada, $\$ 116$ in the United States, $\$ 149$ in Italy, \$174 in France, and $\$ 177$ in West Germany (all figures in Australian dollars). Furthermore, in 1985-6 expenditure on drugs represented only $7 \cdot 8 \%$ of the total health care expenditure in Australia, which is low by international standards (the range is $7 \%-16 \%$ in Europe and North America and 30\% in Japan); in 1960-1 the figure was $23 \%$ in Australia. Total health expenditure in Australia is $7 \cdot 5 \%$ of gross domestic product, which is in the mid to low range for developed countries.

Despite the success of the scheme in containing costs the government remains concerned about the current expenditure on drugs and worries that new drug developments may generate a rapid escalation in costs. These worries stem from the cost to the scheme of drugs such as angiotensin converting enzyme inhibitors and diltiazem and the potential high costs of new drugs such as tissue plasminogen activator and simvastatin. The underlying rate of increase in costs in 1983-8 was $14 \%$, but in $1986-7$ it rose to $19 \cdot 8 \%$ and in $1987-8$ to $27 \cdot 5 \%$. The total cost in $1986-7$ was $\$ A 715 \mathrm{~m}$ and in $1987-8$, $\$ A 911 \mathrm{~m}$.

At the end of last year in response to requests from the pharmaceutical industry for fairer prices the government announced a series of proposals: to replace the pharmaceutical benefits pricing bureau with an independent authority that was to take into account the extent of an individual company's Australian pharmaceutical activity when setting or making recommendations on prices and to provide for extensions to patent life on drugs for human use. It also announced two measures intended to offset the additional cost of applying the new pricing guidelines. The first was to reintroduce a generic pricing policy so that a maximum differential of 20 cents would apply between alternative brands of the same drug; the second was to reduce the wholesalers' margin from $15 \%$ to $10 \%$ of the price chemists pay for drugs.

During 1988, in a further attempt to control drug expenditure, the government introduced an authority system for 53 expensive drugs; this was largely an attempt to control the cost of angiotensin converting enzyme inhibitors. The authority system was originally designed to alert doctors to adverse drug effects, and the fear that it would now be used to 
interfere with prescribing alarmed the Australian Medical Association. The association argued that the new proposal did not deal with the government's real problems-the rapid escalation of the cost of free prescriptions for pensioners and the specially subsidised prescriptions for disadvantaged patients. Together these represent almost three quarters of total costs.

As most of these 53 items were not expensive items the move was seen as misguided, and in partial recognition of this the government has already removed 32 items from the new authority list.

The proposals promote unnecessary conflict with doctors. For example, at one point the government proposed that if an authority was shown to be inappropriate it would recoup the costs of the prescription from the doctor. Moreover, the present publicity has probably exaggerated the value of angiotensin converting enzyme inhibitors and may increase their use and costs long term.

Doctors respond well to the authorny system when it is used to avoid adverse drug effects but poorly when it is used to control costs. After a small hiccup they will probably continue their present prescribing practices by increasing the number of authority requests. Moreover, when frustrated by the authority system they will probably turn to the next most expensive alternatives with little eventual savings. If they need to use two of these drugs to achieve the same effect it may even represent an increased cost to the scheme and no benefit to the patient.

The concerns of the pharmaceutical industry about the implementation of generic pricing have also led to confrontation. Some manufacturers have refused price cuts so that 11 commonly used drugs including glibenclamide, propranolol, and frusemide will be replaced in the scheme by generic drugs. Yet the local generic companies may not be able to maintain adequate supplies; in addition, many patients will be confused by the different product names during the changeover. Another concern arising from the disagreement with the manufacturers is that some manufacturers may not request listing of important new drugs while they remain under patent and charge considerably higher prices for them outside the scheme.

This change in policy may thus destroy the scheme which has been a crucial part of health care in Australia, in that it provides the best drugs at an affordable price to everyone. The government, the doctors, and the industry must all recognise that each has legitimate concerns and that the community needs them to work together. The government needs to recognise that doctors have played an important part in the success of the drug scheme; that the alternatives to drug care are very expensive; that new drugs have the potential to reduce substantially the costs of medical treatment, reduce investigations, and prevent illness; and that more teaching in therapeutics for undergraduates and prescribing doctors is needed. At the same time industry and the Australian Medical Association must recognise that the government needs support in implementing politically unpopular measures to contain costs.

One approach to preserve the present system would be to maintain the current charges for the existing list of drugs and introduce an additional charge for new drugs. This would identify the cost of a new treatment to the patient and the doctor. For the scheme to be successful the community needs to be aware that the new drugs are expensive and that the extra cost will be subsidised-but at a premium. This message will have considerably more impact if it has the support of both the government and the Australian Medical Association.

The alternative is to restrict the prescribing of new drugs, which, inevitably, will lead to a two tier system in which disadvantaged patients are denied access to the best care - this is not acceptable.

Professor of Clinical Pharmacology and Therapeutics,

W J LOUIS

University of Melbourne,

Austin Hospital,

Heidelberg, Victoria 3084

Australia

I Scott C, Fougere G, Marwick J. Choices for health care. Report of the health benefits review. Wellington, New Zealand: New Zealand Government Printer, 1986:27.

\section{Hip fractures in the elderly: beyond the metalwork}

\section{Cooperation between orthopaedic surgeons and geriatricians should pay off}

Proximal femoral fracture is becoming commoner because its age specific incidence is rising in the growing numbers of the very old. ${ }^{12}$ Orthopaedic units, already experiencing difficulties in caring for their elderly patients who have been injured, may expect to admit a lot more over the next few decades, many of them even older and frailer. ${ }^{3}$ Such patients will stay longer and are more likely to require continuing care. ${ }^{4}$ Already elective orthopaedic services are under threat because of pressure on beds from patients who have been injured, ${ }^{5}$ and there is much worse to come. A large Australian study predicts an $83 \%$ increase in bed occupancy due to proximal femoral fracture between 1986 and $2011 .^{3}$

Early surgical intervention by means of internal fixation or arthroplasty is of proved value. But the wide variety of available devices-more than 100 are on the marketsuggests that limits unrelated to mere metalwork are now being encountered. "The fixations are fine," an exasperated orthopaedic surgeon remarks. "It's the bone that's the problem." Other problems that frustrate a good outcome from technically competent orthopaedic surgery for proximal femoral fracture in the elderly include poor mental state, coexistent non-surgical illness, disuse changes related to previous immobility, and social circumstances that were precarious even before the injury.

So there is more to this than orthopaedic surgery. Michael Devas, who with his geriatrician colleague R E Irvine, did so much in Hastings to pioneer the combined geriatric and orthopaedic approach, asserted that the operation is only an incident in rehabilitating the elderly patient with an orthopaedic problem. Since then several other schemes of combined care have been described,,$^{6-8}$ but without rigorous prospective assessment their value has been questioned. ${ }^{9}$

Two randomised trials of rehabilitation after proximal femoral fracture have recently been published. Gilchrist et al compared the performance of an orthopaedic geriatric unit with a traditional consultation service for patients in orthopaedic beds. ${ }^{10}$ Using no additional resources, they succeeded in recognising and treating more medical problems but failed to show any significant impact on mortality, length of stay, or eventual placement. Kennie et al reported more 